$\begin{array}{ll}\text { Abstracta Iranica } & \begin{array}{l}\text { Abstracta Iranica } \\ \text { Revue bibliographique pour le domaine irano-aryen }\end{array} \\ & \text { Volume } \mathbf{2 3} \text { | } \mathbf{2 0 0 2} \\ & \text { Comptes rendus des publications de } \mathbf{2 0 0 0}\end{array}$

\title{
Islamic Mysticism - A Short History. Leiden, Brill, 2000, 358 p.
}

Pierre Lory

\section{OpenEdition}

1 Journals

Édition électronique

URL : http://journals.openedition.org/abstractairanica/35589

DOI : 10.4000/abstractairanica.35589

ISSN : 1961-960X

Éditeur :

CNRS (UMR 7528 Mondes iraniens et indiens), Éditions de l'IFRI

\section{Édition imprimée}

Date de publication : 15 mai 2002

ISSN : 0240-8910

\section{Référence électronique}

Pierre Lory, «Islamic Mysticism - A Short History. Leiden, Brill, 2000, 358 p. », Abstracta Iranica [En ligne], Volume 23 | 2002, document 217, mis en ligne le 08 février 2010, consulté le 25 septembre 2020. URL : http://journals.openedition.org/abstractairanica/35589 ; DOI : https://doi.org/10.4000/ abstractairanica.35589

Ce document a été généré automatiquement le 25 septembre 2020.

Tous droits réservés 


\section{Islamic Mysticism - A Short History. Leiden, Brill, 2000, 358 p.}

\section{Pierre Lory}

1 Il existe déjà un certain nombre de présentations générales du soufisme en français, en anglais et dans les autres langues occidentales. Le présent ouvrage ne vient cependant faire double emploi avec aucun autre. Cela revient à son ampleur d'abord : l'A. prend la place de décrire posément la naissance des différents mouvements mystiques, leur évolution au cours du Moyen Age jusqu'à l'époque moderne, les sources écrites dont nous disposons à leur endroit, des éléments de leur expression doctrinale ou poétique. D'autre part, son attitude scientifique, insistant sur la mise en contexte historique et géographique de chaque personne ou groupe mystique, est jointe à une connaissance très sûre des sources et des faits. L'ouvrage se fonde enfin sur une bibliographie récente qui lui permet maintes mises à jour utiles. L'ensemble fournit un aperçu complet du 'soufisme' depuis les premiers cloîtres au $2^{\mathrm{e}} \mathrm{s}$. A.H. jusqu'aux phénomènes confrériques contemporains. Bref, il vient combler un réel besoin d'une présentation globale mais précise d'un phénomène que le grand public ne connaît souvent que de façon parcellaire ou déformée.

INDEX

Thèmes : 8 . Soufisme 
AUTEURS

PIERRE LORY

EPHE - Paris 